\title{
How? - Where To? About the Changes and Challenges of Adult Education in Poland in the Years 1989-2013
}

\author{
Tomasz Maliszewski ${ }^{1, *}$, Hanna Solarczyk-Szwec ${ }^{2}$ \\ ${ }^{1}$ The Faculty of Education and Philosophy, Pomeranian University, Slupsk, Poland \\ ${ }^{2}$ The Faculty of Educational Sciences, Nicolaus Copernicus University, Torun, Poland \\ *Corresponding Author: pedtm@apsl.edu.pl
}

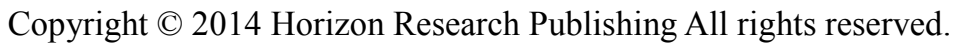

\begin{abstract}
The purpose of this article is to present the changes that have taken place in Polish adult education in the years 1989-2013 under the influence of multiple factors, i.e. social, economic, political and those relating to civilization on the whole. This article is an attempt to answer the following questions: does modern adult education in Poland meet the expectations of society?; is it a driving force behind modernization?; and - does it respond to the needs of the modern labour market? These issues have been presented in an international context, in the light of statistical data and from the perspective of original reading of the literature of the subject.
\end{abstract}

Keywords Formal, Non-Formal and Informal Adult Education in Poland, Educational Activity of Polish Adults, Conditions for the Development of the Intellectual Capital of Poles

\section{Introduction}

Far-reaching transformations have taken place in the Polish educational system ever since 1989. The new socio-political-economic system, liberated from the chains of real socialism and centralism of management of all aspects of life in Poland, "imposed" transformation on all educational levels. It was also an important stimulus for change within Polish adult education. Civilizational change occurring in the last 25 years around the world, dynamic to a degree perhaps never before experienced in human history, also became another key driver for its reform. Thus, in a sense, the current situation of adult education in the Polish Republic is a result of both of these groups of processes, i.e. the internal ones resulting from the change of the political system in Poland and the approach to this issue of national policy makers and other organizers of the learning space, and the external ones associated with global modernization transformations and trends observed on the international arena and / or those imposed by Polish participation in the activities of the structures of different international entities
$[1,2]$.

The three main questions that are worth answering, to introduce the reader to the contemporary condition of Polish adult education, can be formulated as follows:

A. Does the state of Polish adult education today meet the expectations of society, after more than two decades since the collapse of real socialism and the beginning of Poland's (re)construction of fully democratic structures of a civil state and society?

B. Is adult education, as happens in many other countries of the modern world, the driving force behind socio-economic development and, therefore, an important part of the comprehensive modernization of the Polish Republic?

C. Is the scope and extent of citizen participation in various forms of adult education in Poland (formal, non-formal and informal education) appropriate to the needs / challenges of today's labour market and social life?

\section{Polish Adult Education in the Light of International Challenges}

The Common Declaration of the European Ministers of Vocational Education and Training and the European Commission - Copenhagen Declaration "On enhanced European cooperation in vocational education and training", agreed in autumn 2002, stressed that participation in adult education "is essential for the promotion of employment, active citizenship, personal development and fighting social exclusion (p. 2)" [3]. For many years adult education in societies has been a catalyst for change, opening over subsequent decades universal access to education: in the second half of the 1940s and in the 1950s to elementary education and, with time, vocational (e.g. in Poland and other countries of the former "Eastern Bloc") $[4,5,6]$; in the 1960s and 1970s all over the world to secondary education; and today to higher education [7,8,9]. Thus, it has become one of the major causes of transformations in the social structures of individual countries, especially of a noticeable 
transfer of large groups of citizens from the working class to the middle class and, eventually, also to the upper class. These processes, however, did not bring social equality, as a growing gap between the still insufficient number of those benefiting from education and further training and the large group of those staying away from education became evident.

The above findings confirm the diagnosis provided over the years by, for example, the Organisation for Economic Co-operation and Development (OECD), emphasizing that "for those who have successful educational experience, and who see themselves as able, continuous learning is an enriching experience that heightens a sense of control over their own lives and their own environment. However, for those who are excluded from the process, or who prefer not to participate in it, the dissemination of lifelong learning can only have the effect of deepening isolation from the world of those "rich in knowledge". This results in economic consequences, involving the under-utilization of human potential and increased spending on social assistance, as well as social consequences in the form of alienation and declining social infrastructure" [10].

Thus, in the last 25 years, education has been promoted to the rank of capital, which is worth investing in because it determines, much more so than in the past, the quality of human life and an individual's social position. A good education gives you a chance to live in the socio-economic mainstream of your country, whereas qualifications inadequate to the needs of the labour market and the various conditions of social life can become a cause of social exclusion. Therefore, education of citizens is an important indicator of the intellectual capital of each state. This is more and more clearly visible also in Poland. Reference is made in particular to the impact of the level, scope and quality of education of citizens on the development of key components of intellectual capital, such as the following:

- human capital - that is, the potential accumulated in all Poles expressed in their education, life experience gained, attitudes and skills;

- $\quad$ structural capital - that is, the potential accumulated in the infrastructure of the system of education and innovation, i.e. in educational, scientific, and research centres, ICT and intellectual property;

- $\quad$ social capital - that is, the potential accumulated in Polish society in the form of recognized values and standards of conduct, public trust and commitment; relational capital - that is, the potential of the image of Poland abroad, the level of integration with the global economy and attractiveness for its foreign "customers" - business partners, investors and tourists. [11]

The government analyses conducted in Poland indicate that the resources provided in the individual components above can and should become a source of current and future well-being of society [12].

The growing importance of education resulted in extending the period of education in Europe in the years 1970-2000, including by an average of three years in Poland.
At the same time, the working week was reduced from six to five working days. Thus, the overall balance of an individual's free time in the last 50 years has remained unchanged. It can therefore be stated, in some approximation, that an average Pole could, during his or her lifetime, devote as much time as his or her parents did to various forms of adult educational activity. However, the development of modern civilization causes a situation in which the role of education (and qualifications as the final product of the process) has increased significantly. Currently, every adult has to create their educational path consciously. Entering into employment and adult functioning in society, graduates of secondary schools and universities should therefore be aware of the inevitability of having to return to education and be prepared for the following:
a. educational and professional career planning throughout their whole lives,
b. their own educational and professional career management throughout their whole lives,
c. professional and spatial mobility,
d. lifelong learning $[13,14,15]$,
e. participation in the "silver economy" [16]. ${ }^{1}$

In the context of the necessity, apparent in modern times, to change one's job / profession probably several times during one's lifetime, it is not so much the level of education itself, but the individual attitude towards adult education that will determine the social status of individual citizens. The product (sum) of these attitudes will in turn largely affect the potential / intellectual capital across Poland.

\section{Adult Education in Poland - Quantitative Indicators}

Despite the noticeable overall increase in the level of educational aspirations of Polish society in the last two decades, the attitude of less educated persons and those over 40 years of age towards enhancing their own qualifications and, more broadly, towards education in general, stills remains problematic. The Report of the Chief Statistical Office on adult education in Poland at the end of the last decade [17] shows that nearly two thirds of those aged 25-64 $(64.2 \%)$ did not participate in any forms of education or training. Only one in three people $(35.8 \%)$ undertook or continued their education. ${ }^{2}$ Such a rate of participation of adult Poles in various forms of education is, certainly, highly unsatisfactory and shows that building public awareness in this regard becomes a major challenge in promoting lifelong learning in Poland.

\footnotetext{
${ }^{1}$ silver economy - an economic system aimed at exploiting the potential of older people and taking into account their needs - see: http://aktywni45plus.eu/silver-economy-srebrna-ekonomia (date of access: 12-09-2013).

${ }_{2}^{2}$ The report of the Chief Statistical Office [Polish: Główny Urzad Statystyczny - GUS] cited here (Kształcenie dorosłych [Adult Education]. A Report, Warsaw 2009) was developed on a representative sample of 20,634 adult Poles.

Note: All the figures quoted in this article-unless another source has been identified-come from the study.
} 
Among people undertaking their education after the age of 24, every twentieth person has undertaken training in a variety of schools for adults (formal education), nearly every fifth person has studied for extra qualifications at various courses and training events (non-formal education). A quarter of respondents also declared their participation in informal education, understood in the CSO [GUS] statistics as "self-study without the help of a teacher". Detailed data are shown in Table 1.

Four out of five people (80.8\%), working professionals, increased their level of education within the system of formal education, which attests, on the one hand, to a high desire to improve their own qualifications by the working population of Poles, while on the other hand, to the requirements established by many employers, "forcing" their employees to adopt this type of approach. Unfortunately, the participation in formal education of persons falling within the categories of "unemployed" and "economically inactive" does not instil optimism. Barely one in eleven unemployed and just over one in ten economically inactive people confirmed their participation in some form of adult education "school".

The dominant categories of the working population who gained qualifications within the system of formal education were specialists in a field (41\%), technicians and other professionals at the medium level $(18 \%)$, office workers $(10.2 \%)$ and public officials, senior officials and managers (7.5\%). Farmers, gardeners, foresters and fishermen were among those who undertook a form of education/training on the rarest basis (in each case only one in a hundred of them (1.1\%) undertook a form of training in the system of formal adult education).

Employed or self-employed people in areas such as education (19.9\%), public administration and national defence $(14.7 \%$ in total), industrial manufacturing $(12.9 \%)$ and health care and social assistance (11.1\% in total) were among those who undertook a form of education/training on the most frequent basis.

In the light of the quantitative data cited earlier, Poles' participation in formal adult education is not satisfactory. What results, then, in terms of quality does this type of training produce? In this regard, the research conducted among students of schools for adults in one of the southern regions of Poland can be representative of the situation in Polish society as a whole. ${ }^{3}$ Namely, it confirms empirically the low level of autonomy of the respondents, both individual and in learning, and their strong dependence on institutions, repetitive practice of learning and trained patterns of building identity. The respondents pointed to the need for external organization of education and formulated a number of expectations with regard to organizational facilitation, financial aid, and strict control of the learning process itself. They perceive themselves, meanwhile, as compliant participants in education, adhering to rules, and not rebelling against the school as an organization.

The attitude of adult learners can be defined as involved or

\footnotetext{
${ }^{3}$ The research was conducted by Ewa Kurantowicz and Adrianna Nizińska from the University of Lower Silesia] in Wrocław in the years 2009-2011.
}

committed but non-autonomous, that is, they are willing to undertake learning activities, but do not wish or are not able to take responsibility for the quality and progress of the process. Such an attitude results from the poorer educational, cultural and social capital of the backgrounds they come from, and the stiffening of these attitudes is also affected by the culture of learning in institutions of adult education, which goes in the direction of "offering a therapy" to their learners, while when implementing educational activities they turn to the classical repertoire of school teaching methods, though at the same time liberalizing the relationship with students. This is welcomed by students, who thus confine themselves to their educational ghetto, tacitly accepting the measures and practices within the framework defined and provided by the institution and not taking any steps to redefine, criticize or renegotiate them. Nor do these institutions encourage this, since maybe they do not envisage in education the potential for social change, or at most for better adaptation [18]. Regarding extra-mural studies, the situation looks pretty similar in the light of written comments made by students. ${ }^{4}$ Extra-mural studies are considered primarily in terms of adaptation to the labour market, rather than an opportunity to work on one's own identity [19]. Thus, formal adult education performs neither an emancipatory nor critical function, which means that the majority of adults remain passive in the face of social change.

Non-formal education and training (in the form of training sessions) is undertaken in Poland mostly by employed, highly qualified people, having a particular profession, for whom improving their qualifications and gaining new skills is a way to accelerate their careers and promotion at work. Thus, adult education is not used as a strategy to leave the zone of social exclusion, but primarily as a strategy to adjust one's competences to the challenges of the labour market (Table 2).

People active in the field of non-formal vocational education select courses (content) offering hard competences, much less frequently choosing soft ones. When examining forms of education, it turns out that traditional forms of transfer of knowledge, not conducive to discussion, questioning, negotiating widely-held meanings or creativity, still dominate. Therefore, it should not be expected that non-formal education in its present form will contribute to the turn of competence towards autonomy, criticism, and innovation.

What seems worrying is the rate of participation in non-formal education provided in the report of the Chief Statistical Office, showing that only about $25 \%$ of adult Poles declare participation in this form of education. Eurostat estimates, exploring a slightly different statistic since they refer to employed adults, say in turn that only $10 \%$ of this group take part in informal adult learning, allocating for it an average of just over 40 hours per year, placing the Polish Republic in one of the last positions in the European

\footnotetext{
${ }^{4}$ The research was done by Alicja Jurgiel-Aleksander from the University of Gdańsk in Northern Poland in the years 2005-2010.
} 
Union in this regard [20].

If, therefore, following the literature on the subject, we accepted that most of the competences needed in social life are gained informally, and thus informal education is the basic strategy for lifelong learning and formal and non-formal adult education are only complementary forms [21], then it follows that a large part of adult Polish society are becoming more and more helpless (less qualified or competent) facing the demands of the dynamically changing world.
A number of factors differentiating the approach to adult education in different populations can be indicated. The following table (Table 3) shows the impact of a few important ones on making an educational effort in adulthood.

The main reasons for not undertaking any form of formal, non-formal or informal education by Poles after 24 years of age, as provided by the adults themselves, are varied. Table 4 shows a few of them, those most frequently indicated by the respondents.

Table 1. The percentage of Poles aged 25-64 by participation in formal, non-formal and informal education

\begin{tabular}{|c|c|c|c|c|c|}
\hline \multirow{3}{*}{ Specification } & \multicolumn{4}{|c|}{ Persons participating in education: } & \multirow{2}{*}{$\begin{array}{l}\text { Persons not participating in any form of } \\
\text { education }\end{array}$} \\
\hline & in any form & formal & non-formal & informal & \\
\hline & \multicolumn{5}{|c|}{ in $\%$} \\
\hline Total *: & 35.8 & 5.5 & 18.6 & 25.4 & 64.2 \\
\hline $\begin{array}{c}\text { men } \\
\text { women }\end{array}$ & $\begin{array}{l}35.4 \\
36.2\end{array}$ & $\begin{array}{l}4.8 \\
6.2\end{array}$ & $\begin{array}{l}18.2 \\
18.9\end{array}$ & $\begin{array}{l}24.8 \\
26.0\end{array}$ & $\begin{array}{l}64.6 \\
63.8\end{array}$ \\
\hline $\begin{array}{c}\text { in cities } \\
\text { in villages }\end{array}$ & $\begin{array}{l}41.8 \\
25.3 \\
\end{array}$ & $\begin{array}{l}6.7 \\
3.5 \\
\end{array}$ & $\begin{array}{l}22.6 \\
11.4\end{array}$ & $\begin{array}{l}29.6 \\
18.0\end{array}$ & $\begin{array}{l}58.2 \\
74.7 \\
\end{array}$ \\
\hline
\end{tabular}

*Note: the figures do not add up to $100 \%$, because one person could simultaneously participate in several forms of education / training. Source: Chief Statistical Office [GUS], Kształcenie dorosłych [Adult education]. A Report, Warsaw 2009, p 25

Table 2. Participants in non-formal education by the level of their education and status on the labour market

\begin{tabular}{|c|c|c|c|c|c|}
\hline \multirow{3}{*}{ Specification } & \multicolumn{5}{|c|}{ The level of education of participants in non-formal education } \\
\hline & Higher & $\begin{array}{l}\text { Secondary vocational } \\
\text { - including } \\
\text { post-secondary }\end{array}$ & $\begin{array}{c}\text { General } \\
\text { Secondary }\end{array}$ & Vocational & Middle school \\
\hline & \multicolumn{5}{|c|}{$\%$} \\
\hline Employed & 49.9 & 26.9 & 5.9 & 15.0 & 2.4 \\
\hline Unemployed & 29.8 & 30.5 & 9.2 & 22.7 & 7.8 \\
\hline Economically inactive & 36.5 & 25.1 & 19.8 & 9.0 & 9.6 \\
\hline
\end{tabular}

Source: CSO [GUS], Kształcenie dorosłych [Adult Education]. A Report, Warsaw 2009, p 35

Table 3. Factors differentiating the approach to adult education among Poles

\begin{tabular}{|c|c|c|}
\hline No. & Factor & Characteristics \\
\hline 1 & sex & $\begin{array}{c}\text { The people not participating in any forms of adult education in Poland are equally men and } \\
\text { women, thus, sex is not a factor differentiating Polish society in this respect. }\end{array}$ \\
\hline 2 & place of residence & $\begin{array}{c}\text { More than a half of the urban population and as many as three-quarters of the rural } \\
\text { population do not take part in adult education, making the place of residence an important } \\
\text { element differentiating the approach to adult education. }\end{array}$ \\
\hline 3 & Age & $\begin{array}{c}\text { The older people get, the less frequently they benefit from learning opportunities, thus, more } \\
\text { than three quarters of people over 55 years of age do not knowingly undertake any } \\
\text { educational activity any more. }\end{array}$ \\
\hline 4 & level of education & $\begin{array}{c}\text { The highest percentage of those not participating in adult education (about } 4 / 5) \text { occurs in the } \\
\text { group of adults who did not complete secondary education, whereas the lowest one occurs } \\
\text { among adults with higher education. }\end{array}$ \\
\hline 5 & status on the labour market & $\begin{array}{c}\text { In the whole group of those not participating in any form of education, slightly more than a } \\
\text { half are employed, but among the unemployed almost three quarters of Poles undertake no } \\
\text { additional training at all. }\end{array}$ \\
\hline
\end{tabular}

Source: Own study by the authors - from the CSO [GUS], Kształcenie dorosłych [Adult Education]. A Report, Warsaw 2009. 
Table 4. The reasons (excuses?) for failing to make an educational effort in adulthood by contemporary Poles

\begin{tabular}{|c|c|c|}
\hline No. & Reason provided & $\begin{array}{c}\text { The percentage of } \\
\text { adult Poles }\end{array}$ \\
\hline 1 & no such need for their own interests & $44.7 \%$ \\
\hline 2 & no such need in their work & $43.4 \%$ \\
\hline 3 & lack of motivation to resume studying & $40.5 \%$ \\
\hline 4 & too high a price of a course / training & $32.8 \%$ \\
\hline 5 & health problems / age & $32.8 \%$ \\
\hline 6 & lack of time for family reasons & $24.9 \%$ \\
\hline 8 & $\begin{array}{r}\text { lack of an adequate offer close to the } \\
\text { place of work / residence }\end{array}$ & $18.2 \%$ \\
\hline
\end{tabular}

Source: CSO [GUS], Kształcenie dorosłych [Adult Education]. A Report, Warsaw 2009, p 90

\section{Conclusion}

Ever since the collapse of the Polish People's Republic, a satellite to the Soviet Union, more than two decades ago, Polish adult education has undergone a far-reaching transformation. Freeing itself from "unwanted ideology" and centralized management, Polish adult education found itself in a new socio-political and economic situation, in which, step by step, it had to build its position in a more and more democratic country, while also experiencing significant changes itself. On the one hand, attempts continued to be made to save the form and content of adult education from the past through their adaptation to new challenges and tasks while, on the other hand, a number of new institutions / organizations emerged, wishing to organize the educational activity of adult Poles in different ways.

Nowadays, school-based forms of education continue to play the major role on the Polish market of educational services for adults. At the same time, general education is dominated by vocational education, within which institutions with a well-established long-term position, such as continual education centres (CEC) and vocational training centres (VTC) maintain their strong position. In recent years, the apparent development of the education of seniors, especially the universities of the third age and the increase in short-term projects in the field of adult education financed by European Union funds, is also a novelty in the Polish situation.

Still, the ideas of adult education, and more broadly the ideas of lifelong education, require action to disseminate them widely in Polish society. Only well-thought-out PR actions may encourage "resistant" adults, who still account for nearly two-thirds of the adult population of Poland, to take advantage of the educational offer.

A comparative analysis of the current value of the intellectual capital of Poland with the data for 16 other European countries conducted a few years ago by a Team of Strategic Advisers to the Prime Minister [22] showed that different generations of Poles are placed in distant positions, when compared with other European countries. ${ }^{5}$ This means that in this respect the distance between Poland and the most developed European countries is still considerable and significant. Until recently, it was not too big an obstacle to the development of the country, since the competitiveness of the Polish economy was based on advantages such as low labour costs, a large market, and location in the centre of Europe. However, contemporary Polish society and the desire to build a knowledge-based economy require substantial strengthening of the intellectual capital. Investing in education, which determines the course of one's professional career, should be the basis of this process. It is important here to treat both these types of activity, i.e. education and professional work, as a lifelong undertaking.

Referring towards the end of these considerations to the questions posed at the beginning of this article, it must be objectively concluded that there is still much to do in Poland in all the three issues raised here. Thus, the answers at present, as indicated in the content of this outline, would be only partially affirmative. However, both policy makers as well as theoreticians and the relatively large number of practitioners of adult education in Poland are aware of the importance of adult education to building the intellectual capital of the country and preventing the social exclusion of individuals and whole social groups. This in turn gives us hope that in time we will be able to answer each of these questions positively in the Polish context.

\section{REFERENCES}

[1] T. Maliszewski, H. Solarczyk-Szwec, Wstęp, [in:] T. Maliszewski, H. Solarczyk-Szwec (eds), Edukacja dorosłych w Europie. Wybrane aspekty komparatystyczne, Edukacja Dorosłych, Vol.54-57, No.1-4, 9-11, 2007.

[2] T. Aleksander, Globalizacyjne implikacje edukacji dorosłych w Polsce, 348-355 [in:] T. Aleksander, Andragogika, ITeE-PIB, Radom-Kraków, 2009.

[3] Declaration of the European Ministers of Vocational Education and Training and the European Commission, On enhanced European cooperation in vocational education and training, Copenhagen, November 29-30, 2002.

[4] J. Szczepański et al. (eds), Raport o stanie oświaty w PRL, Państwowe Wydawnictwo Naukowe, Warszawa 1973.

[5] M. Pęcherski, System oświaty w Polsce Ludowej na tle porównawczym, Ossolineum, Wrocław 1981.

[6] R. Ślęczka, Zmiany polityczne i ekonomiczne oraz ich wpływ na szkolnictwo zawodowe w Polsce po II wojnie światowej, 247-260, [in:] W. Szulakiewicz (ed.) Przełomy edukacyjne. Dziedzictwo polskiej teorii i praktyki, Adam Marszałek, Toruń 2011.

${ }^{5}$ Respectively, the generation of children and youth is in 13th position in the ranking, the generation of students in 14th position in the ranking, the generation of adults in 15th position in the ranking, and the generation of seniors in 16th position in the ranking. 
[7] J. Delors et al., Learning: the Treasure Within. Report to UNESCO of the International Commission on Education for the Twenty-first Century, UNESCO Publishing, Paris 1996.

[8] J. Field, Lifelong education, International Journal of Lifelong Education, Vol.20, No.1-2, 3-15, 2001.

[9] P. Ainley, M. Andrews, Jak poszerzanie dostępu do edukacji przerodziło się w zwiększoną partycypację w kształceniu: trendy badawcze, Teraźniejszość-Człowiek-Edukacja, Vol.21, No.1, 41-61, 2003.

[10] What Works in Innovation in Education: Combating Exclusion through Adult Learning, OECD, Paris 1997.

[11] Raport o Kapitale Intelektualnym Polski, A Team of Strategic Advisors of the Prime Minister, Warszaw, July 10, 2008.

[12] M. Boni et al., Polska 2030. Trzecia fala nowoczesności. Długookresowa Strategia Rozwoju Kraju. Proposal: Part I \& II, Warszaw, November 17, 2011 [also online: http://zds.kprm.gov.pl/przegladaj-raport-polska-2030] [date of access: 22-09-2013].

[13] S.M. Kwiatkowski (ed.), Kwalifikacje zawodowe na współczesnym rynku pracy, IBE, Warszawa 2005.

[14] T. Aleksander, Optymalizacja pozaszkolnej edukacji zawodowej dorosłych, Impuls, Kraków 1998.
[15] H. Cieślak, Zamierzenia państw w zakresie edukacji zawodowej w korelacji z rynkiem pracy, 261-270, [in:] C. Plewka (ed.), Edukacja. Tradycje - rzeczywistość przyszłość, CDiDN, Szczecin 2005.

[16] http://aktywni45plus.eu/silver-economy-srebrna-ekonomia [date of access: 12-09-2013].

[17] Kształcenie dorosłych. A Report, Chief Statistical Office, Warszawa 2009.

[18] E. Kurantowicz, A. Nizińska, Trajektorie uczenia się w instytucjach kształcenia ustawicznego, Dolnośląska Szkoła Wyższa, Wrocław 2012.

[19] Jurgiel-Aleksander A., Doświadczenia edukacyjne w perspektywie andragogicznej. Studium biograficzno-fenomenograficzne, Uniwersytet Gdański, Gdańsk 2013.

[20] EU - Labour Force Survey, Ad hoc module on lifelong learning, Eurostat 2003.

[21] E. Kailis, S. Pilos, Lifelong learning in Europe, Statistics in Focus. Population and Social Conditions, No. 8, 6-7, 2005.

[22] http://zds.kprm.gov.pl/przegladaj-raport-o-kapitale-intelektu alnym [date of access: 24-09-2013]. 